\title{
RELN wt Allele
}

National Cancer Institute

\section{Source}

National Cancer Institute. RELN wt Allele. NCI Thesaurus. Code C102800.

Human RELN wild-type allele is located in the vicinity of $7 q 22$ and is approximately $518 \mathrm{~kb}$ in length. This allele, which encodes reelin protein, plays a role in extracellular matrix proteolysis, signal transduction and neuronal development. Mutation of the gene is associated with lissencephaly type 2 . 